\title{
A Theoretical Framework Exploring the Relationship between CSR and Brand Equity
}

\author{
Soofi Anwar, University of Stirling (UK), UAE Campus \\ Email:soofi.anwar@stir.ac.uk \\ Nishi Joy, University of Stirling (UK), UAE Campus \\ Email:nishi.joy@stir.ac.uk
}

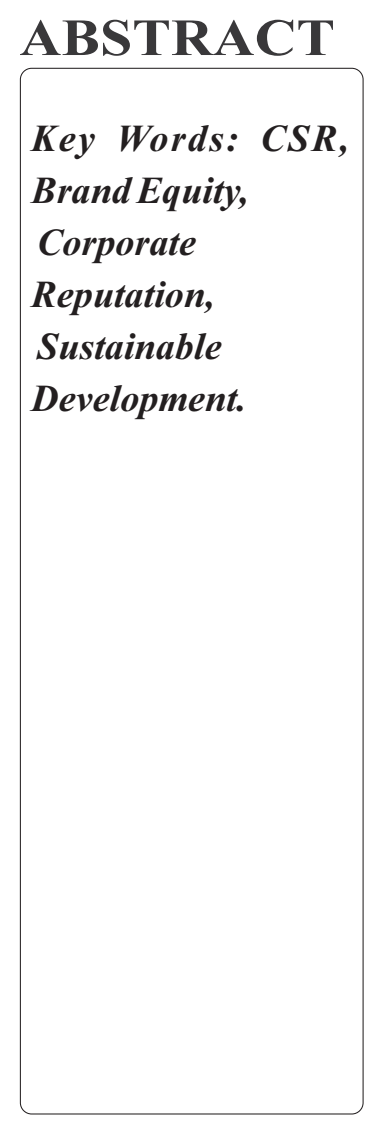

Corporate Social Responsibility (CSR) is the moral obligation of a firm to serve the society beyond meeting its economic and legal goals and responsibilities. An ideal firm should integrate these responsibilities into their ethical code of conduct and serve the public through their products/services. Instead of using it as a mere marketing technique it should be seen as part of their culture and a necessity for sustainable development in the market. There are different dimensions of CSR which are aimed at the stakeholders of the organization namely community, customers, environment, corporate governance and suppliers. The benefits of CSR are many and goes beyond mere financial gains. CSR initiatives can be employed by a firm to develop and enhance the brand value or brand equity (BE) of a firm. In this particular paper the three dimensions of community, customers and environment are chosen to determine the impact of CSR on Brand Equity (BE). Using different theories like Brand asset evaluator, Aaker and Keller model etc. these benefits of CSR on BE is explained. A theoretical framework is proposed. The model can be used to empirically verify which dimension of CSR has the most impact on the components of BE by firms through administering questionnaires to their consumers. Using the results, each firm can customize and strategically adopt CSR initiatives that will resonate positively with their existing customers as well as capture potential consumers and build a positive image in the public.

\section{INTRODUCTION}

Corporate social responsibility (CSR) is gaining immense popularity in the recent times as more and more firms are actively undertaking CSR activities. CSR initiatives are employed by the firms to build a positive corporate image and reputation in the society. Stakeholders, especially consumers connect well with companies that make an effort to give back to the society.
Indulging in CSR activities by a firm creates a ripple effect, not only is the firm able to establish a reputation but also create a loyal customer base which in turn ensures good financial performance in the long run (Luo and Bhattacharya, 2006).

The 1980s witnessed a new beginning, with many firms recognizing the concept of 'Brand Equity' or the financial value attached to a brand. Management 
teams realized the value of this tangible asset and it's potential to generate monetary benefits in the future. Soon the American and European press started covering information and importance of BE. Many firms from industrial sectors that were not into active promotion and marketing jumped into the bandwagon to consciously create a brand name in the market (Luo and Bhattacharya, 2006).

Corporate societal marketing programs are powerful tools adopted by companies to impact BE through consumer awareness, enhancing brand image, establishing brand credibility, evoking brand feelings, creating a sense of brand community, and prompting brand engagement. Studies reveal that CSR program can result in favourable brand evaluations, stronger customer identification and increased consumer satisfaction. Thus, well designed CSR initiatives are capable of creating a positive and a lasting impact on the minds of consumers as a consequence of which companies can expect financial rewards in the future due to the increased BE (Luo and Bhattacharya, 2006, Sen and Bhattacharya, 2001 and Brown and Dacin, 1997)

\subsection{Aims and Objectives}

The main objective of this paper can be outlined as below:

- to understand the theoretical constructs of CSR and $\mathrm{BE}$

- to explore the implication of the various CSR dimensions on $\mathrm{BE}$

- to develop a conceptual framework to analyse the impact of CSR on BE
In order to understand the theoretical constructs underlying CSR and BE and to better comprehend the implication of the various CSR dimensions and its impact on BE, an extensive analysis of existing literature is carried out and then the conceptual framework has been proposed.

\subsection{Significance and Contribution of the Study}

Existing studies addressing the relationship between CSR and BE often consider single dimensions of CSR, the most popular being donations and philanthropic contributions. However this study attempts to analyse CSR from a wide spectrum of dimensions and its impact on $\mathrm{BE}$ elements and thereby contributing to the existing literature on CSR and BE.

\section{DATAAND METHODOLOGY}

This study is purely secondary data based. An extensive analysis of existing literature pertaining to CSR and BE is undertaken to clearly understand the relationship between the two variables of interest and to subsequently propose an apt theoretical framework that measure the impact of CSR on BE of a firm. To propose a theoretical model, it is essential to understand the existing literature on CSR and $\mathrm{BE}$ rather than using primary data and undertaking an inductive research strategy. An appropriate theoretical model should be able to justify the impacts of its various components and their mediating effects on each other. Hence using secondary research, assessing the existing literature is very crucial to demonstrate the relevancy and relationship of the components of BE with the various dimensions of CSR. 
3. THEORETICAL CONCEPTS UNDERLYING CSRAND BE

\subsection{Corporate Social Responsibility}

Adolf A. William Dodd and Martha Dodd are the scholars to first discuss the CSR issue. Since then the idea of communal societal accountability has garnered a lot of attention and developed a lot from total vagueness. The obligation of the company towards the different stakeholders entrust them with a lot of responsibilities. These can be in different dimensions such as ethical, social, legal and obligation towards the suppliers, customers and investors. Rather than just doing what is necessary the responsibility of the firm urges them to satisfy their stakeholder groups. This can inturn provide the firm with a lot of benefits (Jones, 2005).

A lot of literature suggests a link between CSR initiatives and its ability to create financial sustainability courtesy consumer satisfaction rather than solely focussing on the monetary benefits of the shareholders. While it is important for a firm to ensure shareholder wealth maximization, sustaining the profitability of the firm and returns to the investors can be difficult in long run without considering and catering to the needs of some stakeholder groups. Apart from improved financial performance, there are various other benefits such as long-term sustainability of the company, increased staff commitment and involvement, long-term return on investments, enhanced capacity to innovate, enhanced brand value and reputations, development of closer links with customers, and greater awareness of their needs (Jones, 2005).

In addition to the economic benefits, firms can accrue non-monetary benefits which will translate into monetary gains in the long run. Lichtenstein, Drumwright, \& Braig (2004) studied the impact of CSR initiatives on the consumers' attitude towards the firm. They use perceived CSR as a measure between CSR and customer satisfaction. The results reveal the consumer's attitude towards a firm is positively impacted by the CSR initiatives undertaken by firms.

In summary, CSR is a moral obligation of a firm towards its community or society. It is the acknowledgement and response to issues that are not necessarily economic, technical or legal requirements in nature but societal concerns. Addressing these social concerns in a systematic way through CSR initiatives will help firms to gain economic benefits by virtue of gaining societal trust and increased reputation.

\subsubsection{CSR Dimensions}

As seen in the above section, CSR brings in a plethora of benefits to the company. Theories on CSR is classified on the basis of benefits it brings to the firms. These theories and benefits can also be seen as different dimensions of CSR. The review of available literature shows that there are various theories underpinning the concept of CSR, which in turn can be categorized into four major categories. The following is brief description of the each of the major category. 
1. Instrumental theories: The basic accountability of a firm is to generate wealth. Economic welfare is the only aspect taken into consideration under this category of theory. If communal activities lead to wealth generation of the firms then they will be adopted. Three groups of instrumental theories are recognized in the literature a) exploiting shareholders worth, a short-term profit maximization b) focussing on attaining competitive benefits; a long-term sustainable approach to firm profitability c) cause related advertising, this is related to the second category.

2. Political theories: There is an inherent relationship between commerce and the community and the authority or government forms the crux of this relationship ensuring firms are accountable to their community members. Political theories are characterized by two main approaches such as corporate constitutionalism and corporate citizenship.

\section{Integrative theories: For sustained long run of} any firm is an outcome of meeting the societal demands of important stakeholder groups. Beliefs such as community accountability, stakeholder management and corporate social performance are carefully infused along with everyday management practices to achieve a balance between monetary and non-monetary benefits.

4. Ethical theories: Prescribes that communal accountabilities of a firm are at a higher consideration any other considerations.
There is a more specific way of looking into the responsibilities of a firm as suggested by Carroll (1991)'s pyramid of social responsibility. The many features of CSR can have a strong impact on the well-being of the firm. Carroll's pyramid is divided into four main concerns namely legal, economic, charitable accountability as well as the moral of commercial performance. Meleware and Wooldridge (2001) points out that components of Carroll's pyramid are not to be considered as equally important with communal issues on one side and economic concerns on the other. In order for a firm to function smoothly, at least two of the responsibilities identified by Carroll have to be met. It is not possible for a firm to fulfil its economic goals or responsibilities but ignore or not adhere to the legal requirements. The main role of every business in our society is to fulfil its financial goals by producing goods and services as per the demand requirements of the consumers. The legal requirements to be met by the companies are specified in legislation.

It can be a difficult task for firms to balance between meeting the financial goals and objectives as well as meeting the moral responsibilities. However, firms that fulfil these obligations gets positive media coverage and public attention.

\subsection{Brand and $\mathrm{BE}$}

According to Keller (2013), brand equity is the value that consumers associate with a brand; thus, the power of the brand lies in what customers have learned, felt, heard, and responded to regarding the 
brand over time. As a key indicator of the state of health of a brand (Keller, 1993), brand equity is built through an effective management of the brand. The value of a brand is created by marketers through the brand's superior quality, social esteem the brand provides for users, consumer trust in the brand, and self-identification with the brand (Keller, 1993, 2013; Schiffman and Kanuk, 2007).

Aaker (1991), while defining brand equity as a set of assets and liabilities, conceptualized it as a multidimensional concept consisting of brand awareness, brand associations, perceived quality, and brand loyalty that are important from the customer perspective.

Positive brand equity can help a company in a variety of ways. The most common is the financial benefit which enables a company to charge a price premium for that brand. Positive brand equity can also help to expand a company through successful brand extensions and expansions. And not only can brand equity help increase sales and revenues, but it can also help reduce costs. For example, there is little need for awareness promotions for a brand that has deep, positive equity. Marketing budgets can be more strategically invested in initiatives that will drive short-term results.

There is limited empirical evidence on how brand value is created and its precise effects on a company. Cobb-Walgren, Ruble, and Donthu (1995) undertake a research to understand the effect of $\mathrm{BE}$ on consumer preferences and purchase intentions. The researchers used two sets of brands from the product and service category. One set consisted of brands selected from a service category with high financial and functional risk and the other from a low risk product category. Each set consists of two brands that are perceived to be similar by consumers but have different levels of advertising budget over the past decade. The results reveal that the brand with higher levels of advertising from both the category was preferred by the consumers.

According to Parasuraman (1994) consumers do not evaluate a product or service based solely on its quality but they also take price into consideration. Consumers are satisfied when they receive the desired value from the goods or service for the money they spent. This derivation of desired value for the money spend is a contributing factor to customer trust and loyalty of a brand. Parasuraman (1994) also observed that customers are more willing to buy products and services from a company that is more engaged in social causes, this is also a contributing factor to brand loyalty.

Park and Srinivasan (1994) adopted a surveybased method to measure and understand a brand's equity in the product category. The research takes into consideration a consumer-based definition of $\mathrm{BE}$; an added value to a product or service as a virtue of the brand. The authors' measure BE as the difference between an individual customer's overall brand preference his preference on the basis of objectively measured product attribute levels. To understand the origin of BE, the authors 
divide $\mathrm{BE}$ into attributes based and non attributesbased components. The results reveal that market share and price premium are attributable to $\mathrm{BE}$.

Two basic research approaches to measure brand equity can be broadly classified into firm based and customer-based approaches. Firm based focuses on the monetary or financial value of the brand in the marketplace (Morris, 1996); the second refers to a multidimensional concept that involves the value added to a product or service by consumers' associations and perceptions of a brand name, normally conceptualized as consumer-based brand equity (Aaker, 1991; Keller, 1993).

Two of the most cited consumer-based frameworks are those suggested by Aaker (1991) and Keller (1993). Although they conceptualized brand equity differently, their approach to brand equity relied on consumers' brand associations. Aaker's (1991) framework of brand equity is the most frequently-used model in practice and comprises five sources. Four sources are based on customer perceptions of the brand: brand awareness, perceived brand quality, brand associations/differentiation and brand loyalty.

Keller (1993) takes Aaker's research one step further by offering an alternative model: consumer-based brand equity (CBBE). Just as its name implies, the CBBE model's approach is to gain insights into consumer behaviour; the basic premise of the model is that 'the power of a brand lies in what resides in the minds of customers'
(Keller, 2003). According to Keller's conceptualization of CBBE, 'customer-based brand equity occurs when the consumer has a high level of awareness and familiarity with the brand and holds some strong, favourable, and unique brand associations in memory'.

\subsection{CSR and BE}

CSR has an explicit impact on BE of a firm. It is very important to conduct studies and further understand the dimensions of CSR which contributes to increased $\mathrm{BE}$ of the companies using them. Kitchin (2003) explains the power of CSR in being able to uniquely add value to the firms adopting strategic CSR initiatives. According to the author a brand is a result of a trust a consumer places on a firm. However, often there is a gap between the level of trust a consumer has on the firm. Kitchin (2003) suggests of remedial measures to close or minimize the gap by adopting CSR. He also notes, the BE of a company is highly influenced by people's perception of the firm. Vassileva (2001) in his study also notes that companies having CSR initiatives were able to positively influence the minds of their customers.

The relationship between the customer and the company creates loyalty and trust with the firm. Customer loyalty and trust towards a firm should be consciously built to ensure sustainable profit in the long run. Various literature studies this approach in depth. Bhattacharya's (2003) study reveals that customer loyalty post purchase is increased if the consumers are aware of the CSR initiatives adopted by the firm, which leads to 
overall positive evaluation of the company by the customers. Brown and Dacin (1997) research also reveal a positive relationship between CSR actions of a company and a consumer's reaction to that particular firm. According to Mohr, Webb and Harris (2001) companies are facing increasing pressure to maintain profitability and behave in socially responsible ways. This is where research in these areas can provide a guidance towards industry practitioners.

Hur, Kim and Woo (2014)'s study on a sample of South Korean consumers suggest that firms undertaking CSR initiatives are perceived differently by customers, these firms were able to considerably improve their brand credibility and corporate reputation through CSR initiatives. Another interesting study from Taiwan on insurance policyholders by Hsu (2012) indicates that, customer satisfaction is linked to CSR initiatives. The study found that policyholders were more satisfied with their insurance company if the are aware of the CSR initiatives undertaken by the firm. The consumers perceive firms undertaking relevant CSR initiatives to be more credible and reputable.

Wang, Chen, Kuang Yu, Yi Hisao (2015) explores the relationship between CSR, BE and financial performance of the Taiwanese high-tech firms during 2010 to 2013. The results reveal that CSR has a ripple effect on $\mathrm{BE}$ and financial performance of the firms. Companies that undertake CSR initiatives have a positive corporate image which helps the BE, such companies also performed well financially. The researchers concluded that CSR is capable of impacting the $\mathrm{BE}$ and ensuring sustainable profitability in the on run. Torres, Bijmolt, Tribo and Verhoef (2012) conducts a panel study on 57 global brands originating from various parts of the world. Their study reveals that firms who undertook different CSR initiatives had a positive effect on the global BE of the firm. Also, firms that supported local CSR initiatives and adhered to the community laws received positive support and increased BE. The authors conclude their result by suggesting managers should formulate the appropriate CSR strategy by considering the local sentiments in order to increase the BE positively.

\section{PROPOSED MODEL DEPICTING THE IMPACT OF CSR ON BE}

In this study, three specific dimensions of CSR initiatives namely community, customers and environment are chosen. These three stakeholder groups are identified as important dimensions in various studies on CSR (Bhattacharya \& Sen, 2004; Orlitzky et al., 2003; Sen et al., 2006). There is a paucity of quality research analysing the differential effects of CSR dimensions on these different stakeholders. Wood and Jones (1995) "argue that differential effects of CSR dimensions on performance may occur because the expectations and evaluations of CSR may differ from one stakeholder group to another. The authors further argue that there should be no mismatch between the CSR stake-holder measures used and the studied outcome measure. Hence, they suggest the existence of a positive relationship between CSR dimensions to marketoriented stakeholders (i.e., customers) and market measures." 


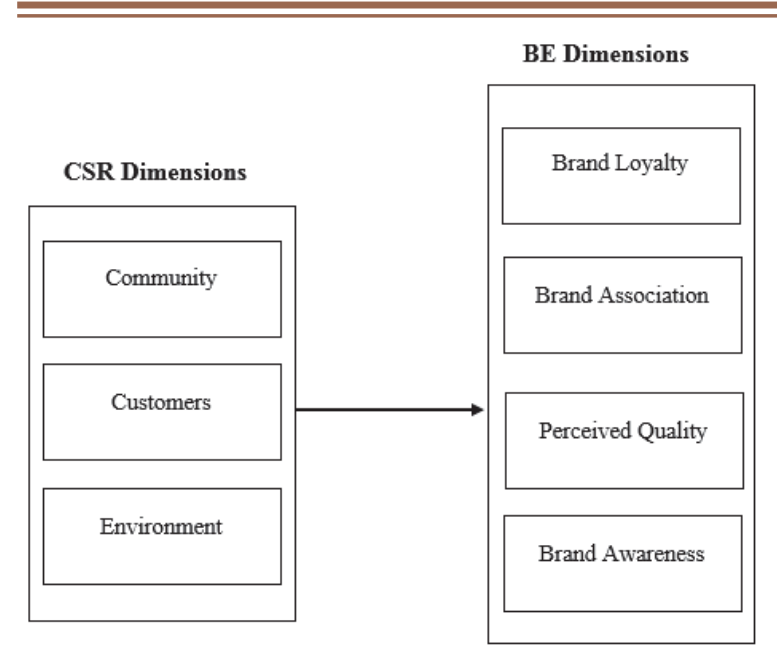

Figure 1. Proposed model depicting the impact of CSR on BE

For the purpose of the proposed model, the CSR dimensions are selected on the basis of Sen and Bhattacharya's (2004) research. Below is a brief discussion on each of the dimensions:

\section{Responsibility towards the Community;} companies rely on their immediate community for getting business. It is partly their responsibility to take care of the community and give back to the society from time to time. The reputation of a company and its closeness to the society give them a sustainable competitive advantage in the long run. Often in order to engage the community, firms may choose to provide sponsorship to local sports and cultural events, additional vocational training places, recruit socially excluded people and through partnerships with communities or donations to charitable activities.

\section{Responsibility towards Customers, firms} have a responsibility to serve the customer by ensuring their products or services offer good value for money apart from ensuring the quality and safety standards. Providing additional support like after sales support and prompt replies to queries and complaints also go a long way in ensuring a satisfied customer base.

3. Environmental; this dimension addresses environmental concerns and sustainable development. Firms should ensure their operations do not contribute to environmental pollution and should adopt sustainable practices in the long run. Often firms undertake extensive reporting on their environmental activities disclosing their sustainable practices and green initiatives undertaken to create awareness among the community.

The brand equity dimensions for the research model are based on Aaker (1991). The description for the brand equity elements is given below:

1. Brand awareness is a key determinant of brand equity. It can be defined as a consumer's ability to recall and recognize a brand (Aaker, 1996; Keller, 2003). Awareness can impact a customer's perceptions, which lead to different brand choice and even loyalty.

2. Brand association contains the meaning of the brand for consumers (Keller, 1993). It is anything linked in memory to a brand (Aaker, 1991). Customers evaluate a product not merely by whether the product can perform the functions for which it is designed for but the reasons to select a particular brand over the competitors (Aaker, 1996) such as brand's fault-free and long-lasting physical operation and flawlessness in the product's physical construction (Lassar et al., 1995). 
3. Perceived quality is defined as the customer's judgment about a product's overall excellence or superiority in comparison to alternative's brand (Zeithaml, 1988, Aaker, 1996) and overall superiority that ultimately motivates the customer to purchase the product (Aaker and Jacobson, 1994).

4. Brand loyalty can be defined as the emotional attachment a customer feels towards a brand in particular. Loyalty can be classified as behavioural and cognitive loyalty (Keller, 1993). Behavioural loyalty refers to repeated purchases or commitment to rebuy the brand as a primary choice (Oliver, 1997). Cognitive loyalty on the other hand refers to the consumers' intention to buy the brand as the first choice

The proposed framework of the model can be employed by firms to understand which dimension of CSR (community, customer or environment) is capable of creating the biggest impact on the various components of BE (namely brand loyalty, brand association, perceived quality, brand awareness) and strategically devise CSR initiatives to increase consumer engagement and build the BE of the firm. Using Likert measurement scale a structured questionnaire can be prepared and administered to target consumers to understand their perceived views on the CSR dimensions and the consequent impacts on the components of $\mathrm{BE}$ can be checked using the correlation tool. The correlation results will provide insights on which the company can work on to strengthen the brand equity using CSR initiatives.
5. CONCLUSIONS AND SUGGESTIONS FOR FUTURE RESEARCH

The paper begins by explaining the concept of CSR activities and BE. If a company's economic, legal, ethical and philanthropic responsibilities are served with a long-term vision in mind and by implementing sustainable social schemes, the firm can build a loyal customer base ensuring a stable and sustainable financial performance in the future. By focusing on CSR activities, the company can also develop and increase their BE, an important contributor to the reputation and value of a firm in the public eye.

This study explores the dimensions of CSR and how it can impact the various components of $\mathrm{BE}$. The proposed theoretical framework explains the link between the select three dimensions of CSR with the BE elements of a firm, applying the Aaker's model of brand equity. Understanding the impact of these CSR dimensions on the BE elements will help the management of a company to strategically take up the CSR activities that can have the most powerful impact on its BE.

It is suggested that the proposed model can be tested using the empirical data to determine the relationship and the impact of the various CSR dimensions on the brand equity of a firm. This can be done either using the customer based brand equity survey to obtain the customer perspective on how these CSR activities influence the brand equity components. Alternatively using firm based method of measuring brand equity and using financial data, the proposed model can be tested to 
establish the link between CSR and BE. Future research can look into the existence of an empirical relationship on CSR ranking or expenditure of renowned companies and their perceived $\mathrm{BE}$ and financial performance. This can be extended as a cross country study on renowned local firms, which will help in identifying if cultural factors or the economic performance of the country and income of people also play an important role in their perceived views of brands and their loyalty and sentiments towards firms and their CSR activities.

\section{REFERENCES:}

1. Aaker, D. A. \& Jacobson, R. (1994). "Study Shows BrandBuilding Pays offfor

2. Aaker, D. A. (1996). "Measuring Brand Equity across Products and Markets, " California Management Review, 38 (3). 102-120.

3. Aaker, D.A. (1991), Managing Brand Equity, the Free Press, New York, NY.

4. Agarwal, M. K., \& Rao, V. R. (1996). An empirical comparison of consumer-based measures of Brand Equity. Marketing letters, 7(3), 237-247.

5. Bhattacharya. (2003). Consumer-company identification: A framework for understanding consumer's relationships with companies. Journal of Marketing, 67 (2), 76-88.

6. Brown, T.J. and Dacin, P.A. (1997), "The company and the product: corporate associations and consumer product response", Journal of Marketing, Vol. 61, pp. 6884.

7. Carroll, A.B. (1991). The pyramid of Corporate Social Responsibility: Toward the Moral Management of Organizational Stakeholders. Business Horizons.

8. Cobb-Walgren, C. J., Ruble, C. A., \& Donthu, N. (1995). Brand Equity, Brand preference \& Purchase Intent. Journal of Advertising, 24 (3), 25-40.

9. David, A. A. (1996). Measuring Brand Equity across Products \& Markets. California Management Review, 38 (3), 0-102.

10. Hsu, K.T., 2012. The advertising effects of corporate social responsibility on corporate reputation and brand equity: Evidence from the life insurance industry in Taiwan. Journal of business ethics, 109(2), pp.189-201.

11. Hur, W.M., Kim, H. and Woo, J., 2014. How CSR leads to corporate brand equity: Mediating mechanisms of corporate brand credibility and reputation. Journal of Business Ethics, 125(1),pp.75-86

12. Jones, P. H. (2005). Sustainable Retailing and Consumerism. Management Research News, 28 (1), 3444.
13. Keller, K. L., \& Lehmann, D. R. (2006). Brands and branding: Research findings and future priorities. Marketing Science, 25(6), 740-759.

14. Kitchin, T. (2003). Brand Management. Vol. 10 (NO. 45), 312-326.

15. Lassar, W., Mittal, B. \& Sharma, A. (1995). "Measuring Customer-Based Brand Equity," Journal of Consumer Marketing, 12 (4). 11-19.

16. Lichtenstein, D. R., Drumwright, M. E., \& Braig, B. M. (2004). The Effect of CSR on customer donations to Corporate-supported non-profits. Journal of Marketing, 68, 16-32.

17. Luo, X. and Bhattacharya, C.B. (2006), "Corporate social responsibility, customer satisfaction, and market value", Journal of Marketing, Vol. 70, pp. 1-18.

18. Luo, X. and Bhattacharya, C.B. (2009), "The debate over doing good: corporate social performance, strategic marketing levers and firm-idiosyncratic risks", Journal of Marketing, Vol. 73 No. 6, pp. 198-213.Means-end Model and Synthesis of Evidence, "Journal of Marketing, 52(3). 2-22.

19. Melewar TC., Wooldridge, W. (2001). The dynamics of corporate identity: A review of a process model, Journal of Communication Management, Vol. 5, No. 4, pp. 327340 .

20. Mohr, L. A., Webb, D. J., \& Harris, K. E. (2001). Do Consumers expect companies to be socially responsible? The Impact of CSR on Buying Behaviour. Journal of Consumer Affairs, 35 (1), 1-28.

21. Orlitzky, M., Schmidt, F. L., \& Rynes, S. L. (2003). Corporate social and financial performance: A metaanalysis. Organization Studies, 24(3), 403-441.

22. Sen, S. and Bhattacharya, C.B. (2001), "Does doing good always lead to doing better? Consumer reactions to corporate social responsibility", Journal of Marketing Research, Vol. 38, pp. 225-44.

23. Sen, S., Bhattacharya, C. B., \& Korschun, D. (2006). The role of corporate social responsibility in strengthening multiple stakeholder relationships: Afield experiment. Journal of the Academy of Marketing Science, 34(2), 158-166.

24. Torres, A., Bijmolt, T.H., Tribó, J.A. and Verhoef, P., 2012. Generating global brand equity through corporate social responsibility to key stakeholders. International Journal of Research in Marketing, 29(1), pp.13-24.

25. Vassileva, B. (2001). CSR-Corporate Branding Relationship. University of Economics-Varna.

26. Wang, D.H.M., Chen, P.H., Yu, T.H.K. and Hsiao, C.Y., 2015. The effects of corporate social responsibility on brand equity and firm performance. Journal of business research, 68(11), pp.2232-2236.

27. Wood, D. J., \& Jones, R. E. (1995). Stakeholder mismatching: A theoretical problem in empirical research on corporate social performance. International Journal of Organizational Analysis, 3, 229-267.

28. Yoo, B. \& Donthu, N. (2001). "Developing and Validating a Multidimensional Consumer-based Brand Equity Scale, ” Journal of Business Research, 52 (1). 114.

29. Zeithaml, V. A. (1988). Consumer perceptions of price, quality, and value: A means-end model and synthesis of evidence. Journal of Marketing, 52(3), 2-22. 